\title{
THE CLASSICAL EDUCATION OF ST. GREGORY PALAMAS THROUGH INDICATIVE EXAMPLES
}

\author{
Soultana D. Lamprou
}

DOI: 10.17846/CL.2017.10.2.126-132

\begin{abstract}
LAMPROU, Soultana D. The Classical Education of St. Gregory Palamas Through Indicative Examples. Saint Gregory Palamas belonged among the greatest fathers of Eastern Church of the 14th century. His intellectual and spiritual potential was cultivated already when he was a student, as he received elaborate education in Constantinople. The intense use of philosophers, among whom Aristotle and Plato were mostly used, and of classical writers, mostly Homer, Sophocles etc., in the writings of Palamas comes as no surprise. In this study, we present an outline of Saint Gregory's classical education with indicative examples drawn from his writings. Through these examples we aim to analyse Palama's method of development and promotion of the national literature ideals to the extent that it led to the definition of true faith, to the knowledge of God and human salvation.
\end{abstract}

Keywords: Homer, Sophocles, Odysseus, Agamemnon, Neoptolemus, Diogenes, philosophy, Plato, Aristotle, Photius, Michael Psellos, Ioannis Italos, Gregory Palamas, Barlaam Kalabros, Gennadius Scholarius, Georgios Plethon Gemistos

\begin{abstract}
Abstrakt: LAMPROU, Soultana D. Klasická vzdelanost'sv. Gregora Palamu prostredníctvom charakteristických príkladov. Svätý Gregor Palama bol jedným z najvýznamnejších otcov Východnej Cirkvi 14. stor. Bol vybavený klasickou gréckou vzdelanostou, kedže dostal vybrané vzdelanie v Konštantínopole. V literárnom diele Palamu neprekvapuje hojné používanie filozofov, hlavne Aristotela a Platóna a klasických autorov Homéra, Sofokla a iných. V tejto štúdii predstavujeme prehladný opis klasického vzdelania svätého Gregora s charakteristickými príkladmi vybratými z jeho literárneho diela, pomocou ktorého analyzujeme spôsob Palamovho zveladovania prínosu národného literárneho dedičstva na úroveň, ktorá viedla $\mathrm{k}$ formulácii pravej viery, k poznaniu Boha a spáse človeka.
\end{abstract}

Klúčové slová: Homér, Sofokles, Odyseus, Agamemnón, Neoptolemos, Diogénes, filozofia, Platón, Aristoteles, Fótios, Michael Psellos, Ján Italos, Gregor Palama, Barlaam Kalabrijský, Gennadius Scholarius, Georgios Gemistos Plethon

Saint Gregory Palamas has been one of the most prominent fathers of the Eastern Church, a prominent figure of the 14th century, who, when he got into a dispute with Barlaam of Calabria and his followers, Akindinus and Nicephorus Gregoras, summarized and codified patristic theology of the previous centuries based on the authority of Scriptures, previous patristic tradition as well as his personal experience. Palamas enriched church literature through his writings and provides us, even today, with a wealth of sources for theological and literary research.

Saint Gregory had received admirable classical Greek education in Constantinople under the protection of emperor Andronicus B'. It is known that already from an early age he was distinguished both for his concentration on and his performance in philosophy. The distinguished scholar of the era and dean of the University of Constantinople, Theodoros Metochites, after 
a discussion with the seventeen-year-old Gregory about the work of Aristotle, said in amazement:

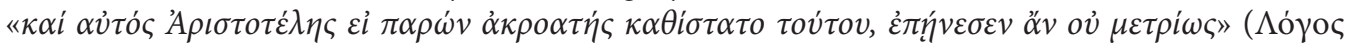

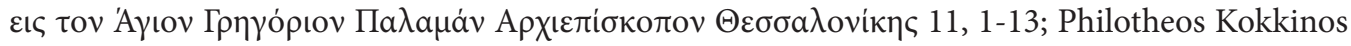
1985, 437-438; Compare Mantzaridis 1973, 41; Zisis 1997, 97).

In the long history of Byzantium, the texts from the ancient Greek literature had been continuously studied. Palamas is aware of the effect the philosophy of Plato and Aristotle had on the formation of the Christian and, more specifically, Byzantine thought. The systematic Aristotelian discourse and the Platonic dialogue contributed significantly to the evolution of Christian views and Byzantine dialectics.

He was also aware of the «dispute» between Aristotelian and Platonic thought in Byzantium. In this «dispute» Aristotle brings the tools of logic within the field of theology, whereas Plato and Neo-Platonists are evaluated on the basis of the autonomy and independence of thought they dictate, and are thus treated as enemies of Christianity (Tatakis 2007, 254-255; Zozulak 2016b, 115). Therefore, there are conflicting tendencies in Byzantine church literature, with writers who opt for Plato's ideas, others for Aristotle's, or even for Stoics'.

The harmonization and complicity of Greek thought and Christian faith that had been achieved by Church Fathers, begins to be disrupted when in the 11th century the humanistic movement is introduced by Michael Psellos. This movement is based upon humanism developed during the era of Photius, who should also be pointed out. Although displaying a clear preference for Aristotle, Photius gave prominence to the superiority of the Christian truths and followed the metaphysics of the Christian teachings, distancing himself from the Platonic and Aristotelian views ${ }^{1}$ (Lamprou 2016, 27; Compare Begzos 1995, 333-336; Benakis 1978 - 1979, 326-327; Zymaris 2000, 19-31; Matsoukas 2001, 299). Of course, Psellos who was also an admirer of Plato, gave prominence to theology rather than to philosophy, and is characteristically mentioned by V. Tatakis (2000, 142) as one who "was able to present a new philosophical composition by turning back both to the tradition of prominent Church Fathers and the Greek education".

However, later the situation became more intense with the introduction of the philosophical system of Ioannis Italos (and that of his students'), in which the effort of ancient philosophy to become autonomous, as well as its effect (mainly the effect of Plato's ideas) on theological issues are evident $^{2}$ (Karmiris 1938, 136-137; Papadopoulos 1970, 46; 67-70; Matsoukas 1970, 55-58). This resulted in the emergence of dogmas contradicting the true faith. In the meantime, let us point out here that in the West the study of Aristotle from the 9th century onwards turned theology into a strict system of truths (Matsoukas 2002, 433).

In his dealing with the question of divine and human wisdom, Palamas refuted this rationalized theology of the 14th century, when Barlaam from Calabria appeared to over evaluate human wisdom, while at the same time attributing to it salvational importance and devaluing the divine. For saint Gregory, the salvation of man did not depend on philosophy and science, but on divine wisdom that is bestowed through the grace of the Holly Spirit after the ascetic cleansing (Lamprou 2009, 222-233).

Palamas' stance towards philosophy, and classical literature in general, reflects the spirit of Church in general and is in complete harmony with the patristic literature. He keeps a hesitant stance; he recognizes the educational value of philosophy in human efforts to understand

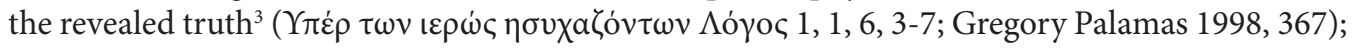

\footnotetext{
As for example he highlights the person rather than the essence and the being.

2 The decisive effect of the Plato and Aristotle is rendered clear in the way both the Eastern and the Western Church theologize.

3 Where Palamas highlights that the preoccupation with rhetoric, logical methodologies, and reasoning
} 
he accepts its effects both on the structure and the content of his work, as he naturally follows practices that are instilled in him by his excellent classical education. On the other hand, he is not reluctant when it comes to criticizing all the fruitless, dangerous and incompatible elements that are in stark contrast with the Christian faith, especially due to his fear of a possible revival of Paganism.

Palamas manages to prove as illusory the line of thinking which considers theology as subjected to philosophy and sciences in general, as if it were a sub field of a genre. He succeeds doing so by pointing out the example of the Greek philosophers who, when they based their knowledge upon

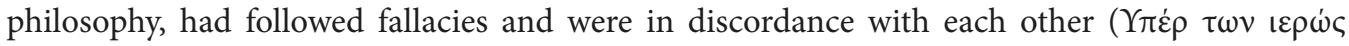

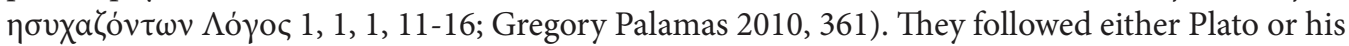
student, Aristotle, who had opposed his teacher. And although they managed to attain the highest level of what was considered encyclical education, having written works that were attributed an utmost importance over the centuries, they were not able to understand the essence of God and His creation, ending up instead in discordance and deadlocks.

Palamas' stance towards secular education, with his clear distinction and exact delimitation of the relationship between theology and philosophy, passed on to his students as well as the ones coming after him. His preference for Aristotle is obvious and understandable - Palamas deemed him less dangerous for the church.

However, during the years before the fall of Constantinople, there was an intense nostalgia for the revival of ancient Greek and Platonic philosophy. The leader of this movement was Georgios Plethon Gemistos who contributed significantly to the knowledge and study of Platonic

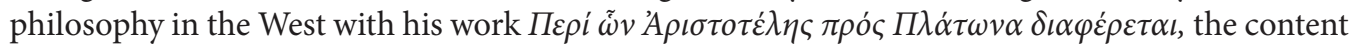
of which was developed in 1438 and during his lectures in Florence (Tatakis 2000, 145-149; Tatakis 2007, 287-296). His treatise had become the main axis around which the conflict between Platonists and Aristotelians re-emerged in Byzantium (Tatakis 1977, 269-278). On the opposing side against Plethon was the supporter of Aristotelian thought, Gennadius Scholarius, the first patriarch of Constantinople after its fall. He writes the following words expressing his clear support

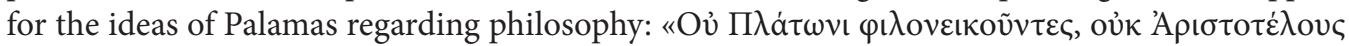

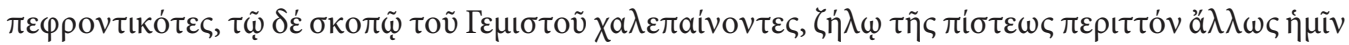

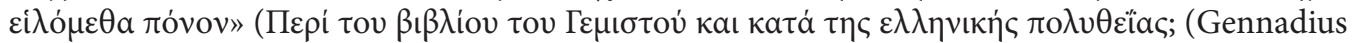
Scholarius 1935, 156; Compare Zisis 1988, 302-303).

In this article, we chose certain references from Palamas coming from ancient literature and we developed further their content so that we could clearly outline how his classical education provided him with the necessary tools to develop his argumentation and express his theological views.

In his $A^{\prime} E \pi \iota \sigma \tau o \lambda \eta \dot{\eta} \pi \rho \circ \varsigma B \alpha \rho \lambda \alpha \alpha \dot{\mu}$ (7, 11-19; Gregory Palamas 2010, 228), Palamas claims that in his effort to acquire real wisdom he has forgotten the reasoning sciences, quoting the phrase

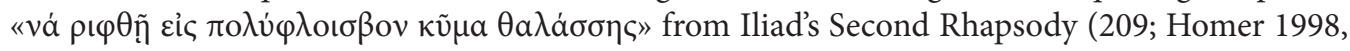
$50)^{4}$. In the same way, he urges Barlaam not to return to a part of his letter that he has already taken

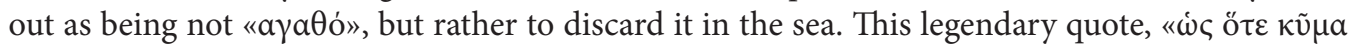
$\pi$ o $\lambda \cup \varphi \lambda$ oí $\sigma \beta$ oเo $\theta a \lambda \alpha$ á $\sigma\rceil \varsigma »$ was used to refer to the loud and turbulent return of the Achaeans from the ships to the army's assembly (following Odysseus' urge), the one they had previously left, when Agamemnon announced his decision to return to their homeland. According to one view, Palamas, knowing the Homeric text, could have been pointing towards a connection between

in general, could be considered beneficial, when it applies seeing through the soul and conveys the efforts to everything that is superior.

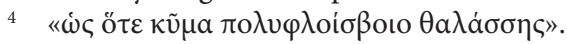




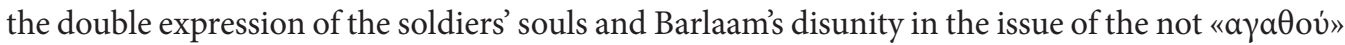
part of his speech removal.

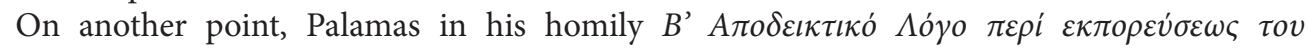

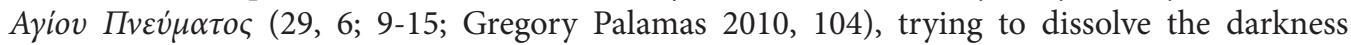
of Barlaam's ignorance, as he characteristically writes. Barlaam's ignorance darkens the means of his understanding and thus he is not able to understand the distinction between the origin and existence of the Holy Spirit, as He originates from the Father and the Spirit's proceeding from the Father and Son. Thus, he criticizes Barlaam because he does not listen to him when he

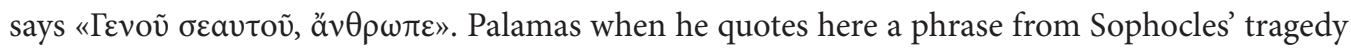
«Philoctetes», brings to our minds the well-known myth of Philoctetes as it is described in Greek literature.

The hero is referred to as an excellent archer who fought in Troy, but after having been bitten by a poisonous snake, he was abandoned by the Achaeans on a deserted coast on Lemnos island, due to the wound that was troubling him and gave off a terrible smell. He remained there alone for ten years, surviving thanks to the weapons of Hercules that he had kept. When Priamus' son, Helenos, who possessed oracular powers, reveals to the discouraged Achaeans after the death of Achilles that in order to seize Troy, Philoctetes had to be with them along with his bow, Odysseus together with Achilles' son, Neoptolemus, take on the task to bring Philoctetes back. The second manages to gain his trust and detach his bow. When, though, he begins feeling sorry for his hypocritical action and reveals his scheme to Odysseus, the hero of the tragedy, using the phrase «'A $\lambda \lambda \dot{\alpha} v \tilde{v} v$

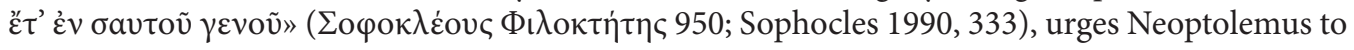
find his noble self and asks him to return the bow, unfortunately with no result.

Palamas reaches the same ascertainment. Just as Neoptolemus before him, Barlaam in the same way does not listen to the advice to «become himself». This is quite clear because if it had not been so, he would have returned to the true faith, he would have accepted the teachings about God and he would not have tried to challenge the teachings of men through words and actions, while at the same time innovating them (B’ A

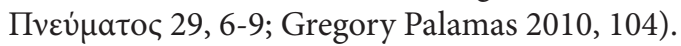

In other points, Palamas confutes the illusions of those who were supporting the idea that the Greek philosophers were enlightened. Instead, he criticizes the philosophers as being vain and their wisdom as being a form of foolishness that opposes the true light. In order to reinforce his

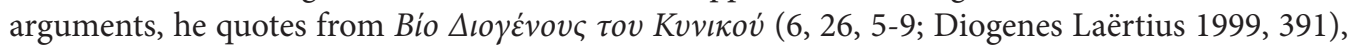
i.e. the discussion between Diogenes and Plato. In this discussion, the cynic philosopher and student of Socrates is inspected by Plato for his actions. To Plato's question «what is it that you are doing Diogenes», he replies that he fights typhus, that is Plato's arrogance, just to receive Plato's

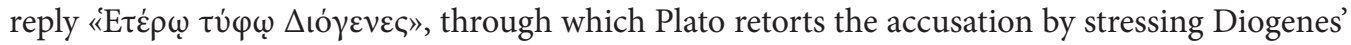
arrogance. Palamas comments on the dispute about arrogance between the two philosophers. The very fact that they debate it points to their admission of it. He also adds that Plato regards vanity as both a virtue and reason of great works, which, when it is absent, leads to a lack of great

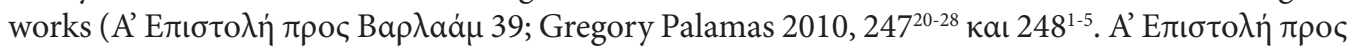
Bap入aá $\mu$ 40, 1-2; Gregory Palamas 2010, 248).

It is not surprising that in Palamas' works there is an extensive use of philosophers, such as Aristotle (Metaphysics), Plato (Timaeus, Phaedrus, Apology) as well as several classic writers, such as Homer, Sophocles, Pythagoras, Plutarch (Ethics, Parallel Lives, Nikias), Xenophon (Memorabilia), Hesiod (Theogony, the Shield of Hercules), Pindar (Olympian Odes), Xenophanes, and others, a fact that points towards his complete literary knowledge. However, a clear view of Palamas' classical education will be provided when our research is complete and will be submitted for publication. 
Palamas' obvious love for and use of classical literature is common in the works of Byzantine scholars and can be justified by the thorough knowledge they had acquired. Palamas knows its importance; in his works, his literary style is vivid, he strengthens his argumentation and he emanates the spirit of the intellectual movement of the era and Byzantine civilization in general. It is particularly interesting that he manages to balance between philosophical discourse and theological accuracy, through which he deals with the theological issues that arose in his era and proves to be a great teacher of the Church as well as an original follower and promoter of patristic tradition.

\section{REFERENCES}

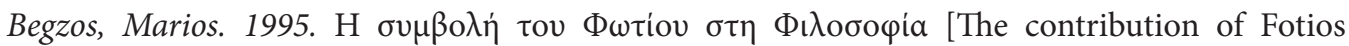

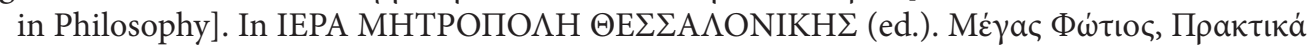

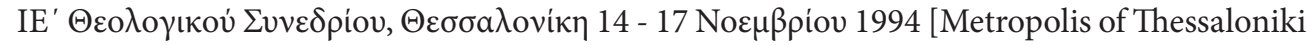
(ed.). Photius the Great, Proceedings of 15th Theological Conference, Thessaloniki $14-17$ November 1994]. Thessaloniki, 327-336.

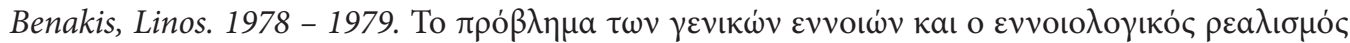

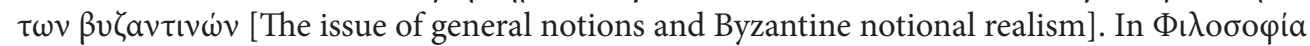
[Philosophia] 8-9, 311-340.

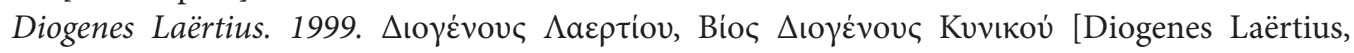
The Life of Diogenes the Cynic]. In Marcovich, Miroslav (ed.). Diogenes Laertius Vitae Philosophorum I. Berlin, 388-428.

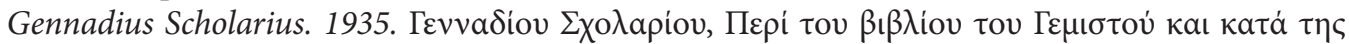

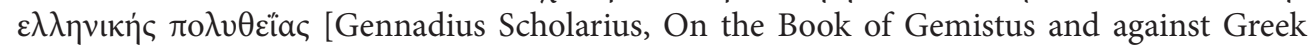
Polytheism]. In Petit, Louis - Sideridès, Xenophon A. - Jugie, Martin (eds.). Гevvadíov tov

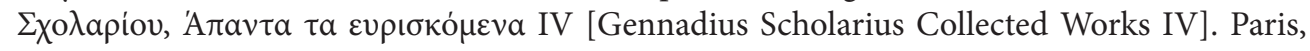
155-172.

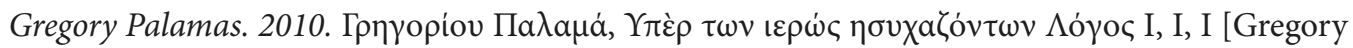

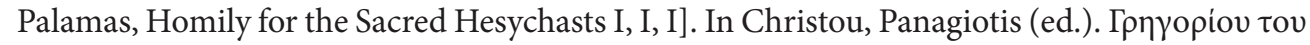

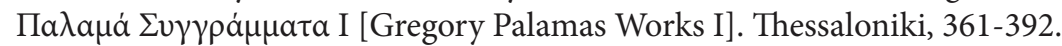

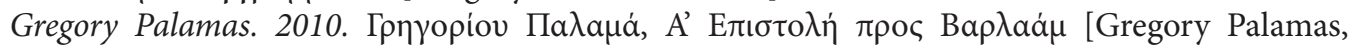

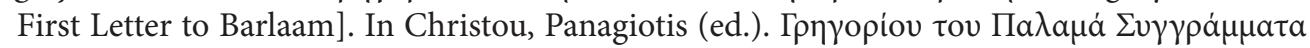
I [Gregory Palamas Works I]. Thessaloniki, 225-259.

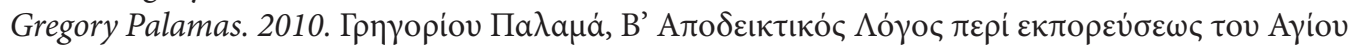

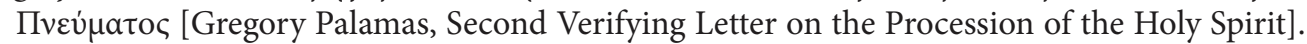

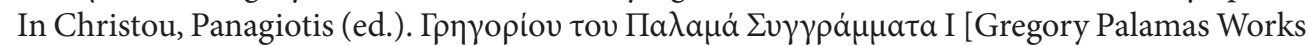
I]. Thessaloniki, 78-153.

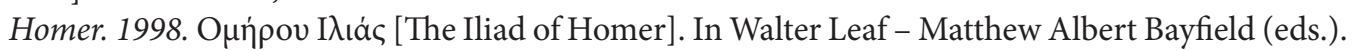
Homeri Ilias I. Stuttgart und Leipzig.

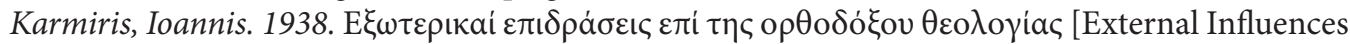

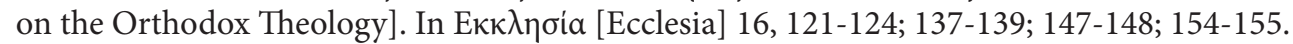

Lamprou, Soultana. 2009. The practice of the teaching of the Three Hierarchs by St. Gregory

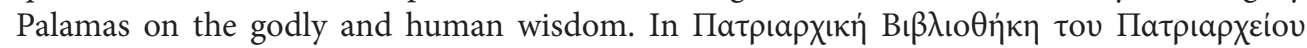

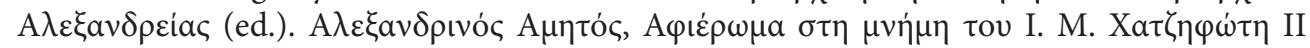
[Patriarchal Library of Alexandria Patriarchate (ed.). Alexandrian Amitos, In the Memory of I. M. Xatzifotis II]. Alexandria, 222-233. 


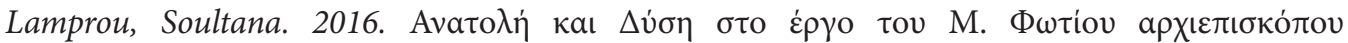

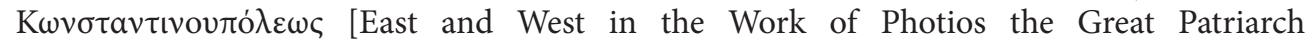
of Constantinople]. In Konštantínove listy [Constantine's Letters] 9/1, 11-28.

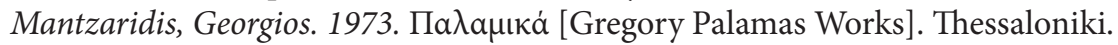

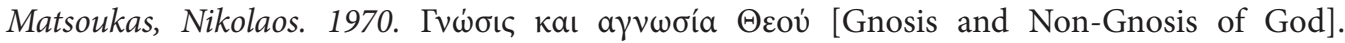
In K入nрovouia [Klironomia] 2, 53-87.

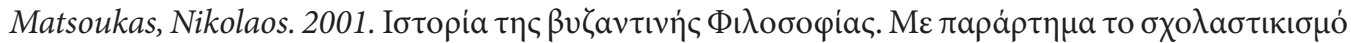

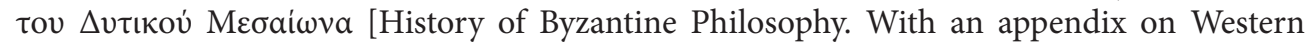
Middle Ages Scholasticism]. Thessaloniki.

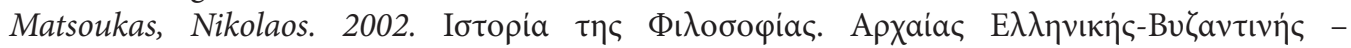

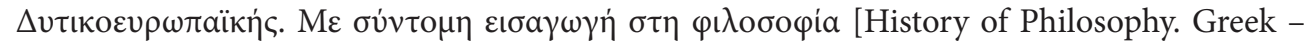
Byzantine - Western European. With a short introduction to philosophy]. Thessaloniki.

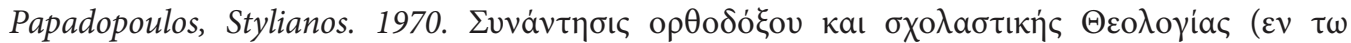

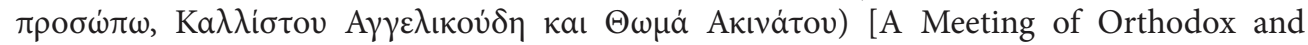
Scholastic Theology (in the meeting of Kallistos Aggelikoudis and Thomas Aquinas)].

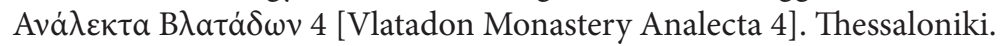

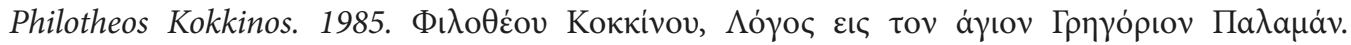

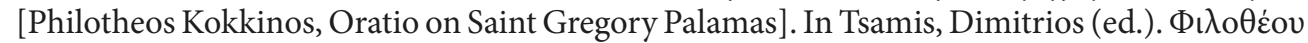

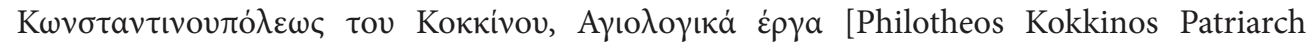

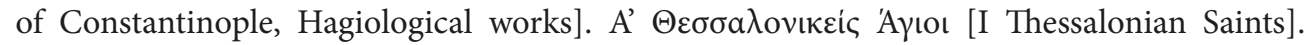

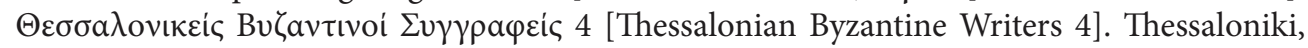
427-591.

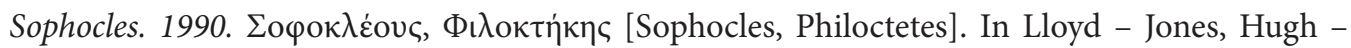
Wilson, Nigel Guy (eds.). Sophoclis fabulae. Oxford, 293-354.

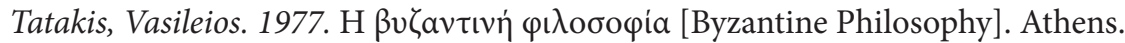

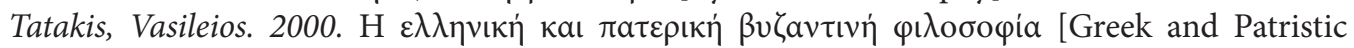
Byzantine Philosophy]. Athens.

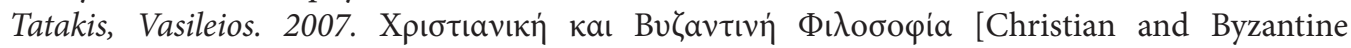
Philosophy]. Athens.

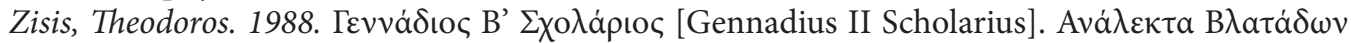
30 [Vlatadon Monastery Analecta 30]. Thessaloniki.

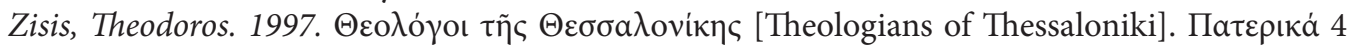
[Patristic Series 4]. Thessaloniki.

Zozulak, Ján. 2016a. Byzantská filozofia. Plzeň.

Zozulak, Ján. 2016b. Historické pozadie vzniku byzantskej filozofie [Historical background of the origin of Byzantine philosophy]. In Konštantínove listy [Constantine’s Letters] 9/1, 110-118.

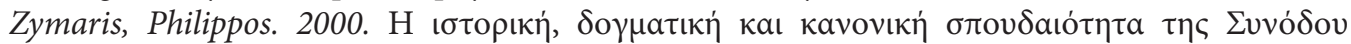

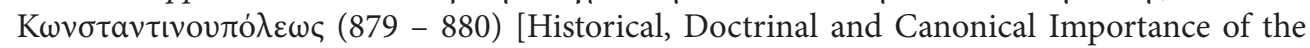

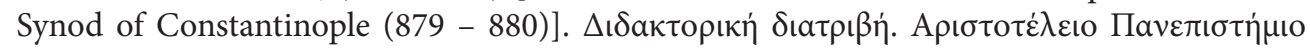

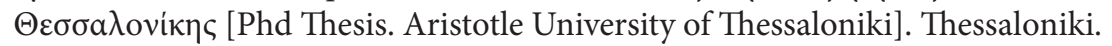

SUMMARY: THE CLASSICAL EDUCATION OF SAINT GREGORY PALAMAS WITH INDICATIVE EXAMPLES. Saint Gregory Palamas belonged among the greatest fathers of Eastern Church, attaining prominence as a theological figure during the 14th century. We need to take into consideration that he received an elaborate education in Constantinople.

Palamite theology reflects the universal notion of the Church. Moreover, Palamas' stance against philosophy and classical literature as a whole conforms to the position of those in the 
patristic literature in general who oppose philosophy. Palamas acknowledges the pedagogical and educational value of philosophy, accepts its influences on the structure as much as on the content of his work, and criticises without hesitation all things that serve no purpose, are dangerous to and incompatible with Christian faith, fearing a possible revival of paganism.

The intense use of philosophers (mainly Aristotle and Plato) and of classical writers (mostly Homer, Sophocles etc.) in the writings of Palamas comes as no surprise.

In this study, we present an outline of Saint Gregory's classical education with indicative examples drawn from his writings. Through these examples we aim to analyse Palama's method of development and promotion of the national literature ideals to the extent that it led to the definition of true faith, to the knowledge of God and human salvation.

Soultana D. Lamprou ThDr.

Aristotle University of Thessaloniki

Faculty of Theology

Department of Holy Scripture and Patristics

Faculty of Theology - School of Pastoral and Social Theology

54124 Thessaloniki

Greece

slabrou@past.auth.gr 